\title{
Cloning, Expression, and Purification of a Lipase from Psychrotrophic Pseudomonas mandelii
}

\author{
Junsung Kim and Chang Woo Lee*
}

Department of Biomedical Science, Daegu University, Gyeongsan 712-714, Korea

Received February 8, 2012 /Revised March 13, 2012 /Accepted March 13, 2012

\begin{abstract}
A gene encoding a lipase, lipT, was cloned from the psychrotrophic bacterium Pseudomonas mandelii and sequenced. An open reading frame of 1,686 bp was found that encodes a polypeptide consisting of 562 amino acid residues. Sequence analysis revealed a Gly-His-Ser-Leu-Gly sequence, which matches the consensus Gly-X-Ser-X-Gly motif conserved among lipolytic enzymes. The recombinant LipT protein was predominantly expressed as inclusion bodies in Escherichia coli and subsequently purified by nickel-chelate affinity chromatography. A small fraction of LipT was refolded, and the subsequent LipT exhibited substrate preferences for p-nitrophenyl butyrate (C4) and p-nitrophenyl octanoate (C8).
\end{abstract}

Key words : Lipase, Pseudomonas fluorescens, Pseudomonas mandelii, Psychrotrophic Bacterium

\section{Introduction}

Lipases (EC 3.1.1.3) from cold-adapted bacteria play important roles in industrial applications due to their high enzymatic activity at low temperatures [9]. These applications include the use of immobilized lipases as additives in low-temperature laundry detergent formulations, the treatment of chilled dairy product in the food industry, and as catalysts for developing new therapeutic agents in the pharmaceutical industry $[9,18]$.

Lipases belong to the $a / \beta$-hydrolase superfamily and consist of a single domain molecule [8]. Lipases act on esters of long-chain fatty acids which are insoluble in water, whereas esterases act on esters of short-chain fatty acids which are water soluble [3]. The lipase active site contains a catalytic triad consisting of serine, histidine, and aspartate residues [8]. Although lipases share a common catalytic mechanism and structure, they show low levels of sequence similarity at the amino acid level [6].

In this study, we utilized the genome sequence of Pseudomonas fluorescens Pf0-1 [17], to which the psychrotrophic bacterium Pseudomonas mandelii showed high homology. A gene coding for a lipase, lipT, was cloned from $P$. mandelii JR-1 using primers based on the non-coding region sequences surrounding the $P$. fluorescens Pf0-1 lipase gene (UniProt ID: Q3KCS9). The recombinant LipT protein, which was mostly expressed in E. coli BL21 (DE3) as in-

*Corresponding author

Tel : +82-53-850-6464, Fax : +82-53-850-6469

E-mail : leec@daegu.ac.kr clusion bodies, was purified using nickel-chelate affinity chromatography. After refolding, LipT exhibited substrate preferences for $p$-nitrophenyl butyrate (PNPB) and p-nitrophenyl octanoate (PNPO).

\section{Materials and Methods}

\section{Materials}

The TA cloning vector was purchased from Enzynomics (Korea). The pET28a expression vector was purchased from Novagen (USA). The HisTrap FF column was purchased from GE Healthcare (USA) and the esters for $p$ Nitrophenyl were purchased from Sigma (USA). All other reagents were obtained from Sigma unless noted otherwise.

\section{Strain isolation and identification}

P. mandelii JR-1 was isolated from natural mineral waters collected in Gyeongsan, Korea. Gram staining was performed as described previously [12]. The 16S rRNA sequencing was carried out at Genotech (Korea). The $16 \mathrm{~S}$ rRNA sequence analysis of the isolated bacterium was carried out using an EzTaxon server [4].

\section{Plate assay for lipase}

Rhodamine B agar plates were prepared as described previously [10]. Holes of $3 \mathrm{~mm}$ diameter were punched into the agar and the cavities formed were filled with either 10 $\mu \mathrm{l}$ of bacterial culture or cell-free culture supernatant. Plates were incubated overnight at $25^{\circ} \mathrm{C}$, exposed to UV irradiation $(350 \mathrm{~nm})$, and then photographed. 


\section{Gene cloning of lipT}

The lipT gene was cloned from $P$. mandelii JR-1 by polymerase chain reaction (PCR) in two steps. First, primers were designed based on the non-coding region sequences surrounding the lipase (Q3KCS9) in the $P$. fluorescens Pf0-1 genome. The forward primer was 5'-GACCACGGTGT GGGCTTGAC- $3^{\prime}$ and the reverse primer was 5'-GCTCACAACCAGAACGCCCC-3'. The resulting PCR product was subcloned into a TA vector and sequenced. Second, the gene for lipT was amplified from the TA vector and subcloned into a pET28a vector. The forward primer used was 5'-GAGAGAtctagaAAGGAGATATACATGGGA CTGTTTGATTAC-3' (Xba I site in small letters, ribosome binding site sequence underlined and the 5 '-end region of lipT in bold face type). The reverse primer used was 5'-GCGGCCGCaagcttCGCAAACGTGATGCCTG-3' (Hind III site in small letters and the $3^{\prime}$-end region of lipT in bold face type). A linker and $\mathrm{His}_{6}$ sequence (KLAAALEHHH $\mathrm{HHH}$ ), which comes from a pET28a vector, were located on the C-terminus of LipT. The construct was confirmed by DNA sequencing.

\section{Sequence analysis}

A homology search was performed using BLAST (http://www.ncbi.nlm.nih.gov/BLAST/). Multiple sequence alignments were performed using ClustalW (http://www.ebi.ac.uk/Tools/msa/clustalw2/).

\section{Expression and purification of LipT}

The gene for LipT with a C-terminal His 6 sequence was transformed into E. coli BL21 (DE3). A single colony grown on an LB/kanamycin plate was selected for additional overnight growth at $37^{\circ} \mathrm{C}$, followed by inoculation into a $250 \mathrm{ml}$ $\mathrm{LB} /$ kanamycin broth. At the mid-log phase $\left(\mathrm{OD}_{600 \mathrm{~nm}}=\right.$ $0.6 \sim 0.8)$ the growth temperature was lowered to $30^{\circ} \mathrm{C}$. After addition of $1 \mathrm{mM}$ IPTG, the cells were grown for 4 more hours. The cells were harvested at $10,000 \times g$ for $5 \mathrm{~min}$. The pellet was resuspended in Buffer A $(20 \mathrm{mM}$ Tris $\cdot \mathrm{Cl}, 0$. $1 \mathrm{M} \mathrm{NaCl}, 5 \%$ glycerol, $\mathrm{pH} 8.0$ ) followed by sonication at $4^{\circ} \mathrm{C}$. After centrifugation at $12,000 \times g$ for $10 \mathrm{~min}$, the pellet was resuspended in Buffer A with $8 \mathrm{M}$ urea. The imidazole concentration was adjusted to $5 \mathrm{mM}$ in preparation for purification using nickel-chelate affinity column chromatography. LipT was purified on an AKTA Explorer system (GE Healthcare) with a 1-ml HisTrap column using Buffer B (20 $\mathrm{mM}$ Tris $\cdot \mathrm{Cl}, 0.1 \mathrm{M} \mathrm{NaCl}, 8 \mathrm{M}$ urea, $70 \mathrm{mM}$ imidazole, $5 \%$ glycerol, $\mathrm{pH}$ 8.0). All purification steps were carried out at $4^{\circ} \mathrm{C}$. The purified enzymes were frozen in $\mathrm{N}_{2}$ and stored at $-80^{\circ} \mathrm{C}$.

\section{Enzyme assay}

The substrate specificity of LipT for $0.4 \mathrm{mM}$ pnitrophenyl esters ( $\mathrm{C} 2$ to $\mathrm{C} 16)$ was measured in reaction buffer $(100 \mathrm{mM}$ Tris $\cdot \mathrm{Cl}, 100 \mathrm{mM} \mathrm{NaCl}, 0.3 \%$ Triton X-100, pH 8.5). The accumulation of $p$-nitrophenol was measured using a Shimadzu UV-160 spectrophotometer at $400 \mathrm{~nm}$ for $5 \mathrm{~min}$ at $25^{\circ} \mathrm{C}$.

\section{Nucleotide sequence accession number}

The nucleotide sequence of the lipT gene from $P$. mandelii JR-1 has been deposited in GenBank under accession number JQ284021.

\section{Results and Discussion}

\section{Strain identification and phylogenetic analysis}

Taxonomical studies based on the $16 \mathrm{~S}$ rRNA sequence revealed homology to the genus Pseudomonas (Fig. 1). Analysis using the EzTaxon server showed it possessed the highest level of similarity to Pseudomonas mandelii (100\%), followed by Pseudomonas cannabina (99.53\%) and Pseudomonas tremae $(99.46 \%)$. A BLAST search of the NCBI database also confirmed high degrees of similarity to $P$. mandelii strains. $P$. mandelii is classified as belonging in the $P$. mandelii subgroup of the Pseudomonas fluorescens group [13].

\section{Optimum growth temperature}

As demonstrated by Gratia et al. [7], P. mandelii grew at $4^{\circ} \mathrm{C}$ but did not grow at $37^{\circ} \mathrm{C}$. Although $P$. mandelii JR-1 is a psychrotrophic bacterium, its optimum growth rate was at $25 \sim 30^{\circ} \mathrm{C}$ (data not shown).

\section{Investigation of lipase activity}

To investigate $P$. mandelii lipase activity, we utilized agar plates containing olive oil and rhodamine B as previously demonstrated by Kouker and Jaeger [10]. Free fatty acids released from the olive oil formed colored complexes with rhodamine B, which is a basic dye. Upon UV irradiation, orange fluorescence was observed for the $P$. mandelii culture on the rhodamine B agar plates, whereas no fluorescence was observed for $E$. coli (Fig. 2). The $P$. mandelii culture supernatant also revealed orange fluorescence (data not 


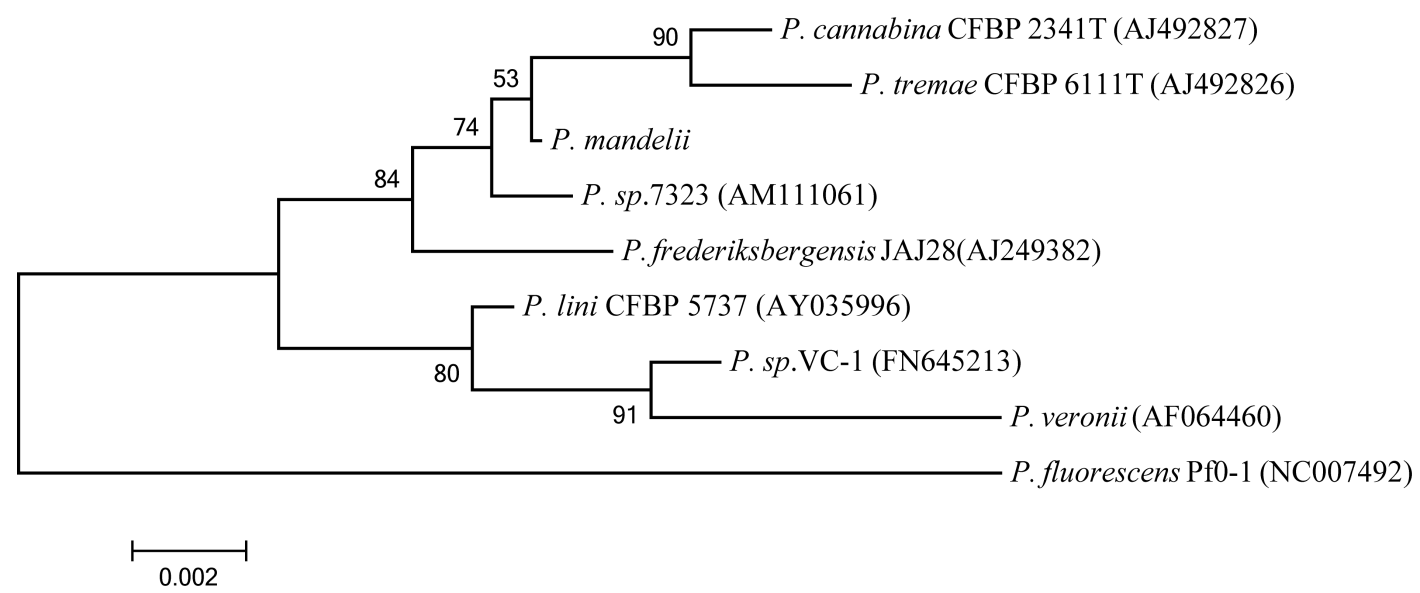

Fig. 1. Phylogenetic tree based on the $16 \mathrm{~S}$ rRNA gene sequence of $P$. mandelii JR-1. $P$. mandelii belongs to the $P$. mandelii subgroup of the $P$. fluorescens group [13].

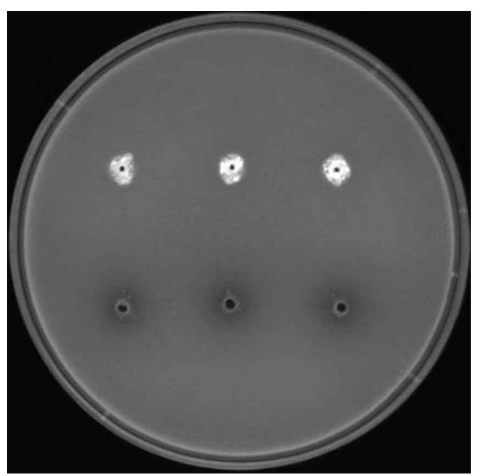

P. mandelii

E. coli

Fig. 2. Identification of lipase activity on a rhodamine $B$ agar plate. After overnight incubation at $25^{\circ} \mathrm{C}$, plates were exposed to UV irradiation at $350 \mathrm{~nm}$.

shown). Our data indicated that $P$. mandelii produced lipase activity, of which, some was exhibited by extracellular lipases.

\section{Cloning of the lipT gene}

Generally, a bacterium expresses several genes of lipases and esterases, possibly reflecting a wide range of substrate specificities. We used two lipase-prospecting primers (OXF1-ACR1 and OXF1-ACR3), as reported by Bell et al. [2], to clone lipase genes from $P$. mandelii JR-1 (data not shown). Although sequencing of the PCR products did not locate a lipase, a BLAST search revealed that the sequences had the highest degree of homology to those of $P$. fluorescens Pf0-1 from among the repository of completed microbial genomes (data not shown). Thus, the PCR primers were designed based on the non-coding region sequences surrounding four $P$. fluorescence pf0-1 lipases, found as lipase in the UniProt database (UniProt ID: Q3KBP5, Q3KCS8, Q3KCS9, and Q3KIU1). A PCR product was amplified from the non-coding region sequences surrounding a lipase (Q3KCS9), subcloned into a TA vector, and then sequenced. A 1,689-bp lipT gene amplified from the TA vector was subcloned into a pET28 vector. Surprisingly, both the lipT and the $P$. fluorescens $\mathrm{Pf0}-1$ lipases had the same 1,689-bp sequence length.

\section{Sequence analysis}

The deduced LipT amino acid sequence comprised 562 amino acids residues. LipT contained a Gly-His-Ser-Leu-Gly sequence, a motif characteristic of the serine lipase family (Gly-X-Ser-X-Gly) [16] (Fig. 3). Sequence analysis also showed that LipT contains six motifs (Gly-Gly-X-Gly-X-Asp or Gly-X-X-Gly-X-Asp) which function as the C-terminal signal for identification by $\mathrm{ABC}$ transporters [1,5] (Fig. 3). LipT showed $83 \%$ sequence similarity at the amino acid level to the $P$. fluorescens Pf0-1 lipase (Q3KCS9).

\section{Expression and purification of LipT}

An entire open reading frame of lipT with a C-terminal $\mathrm{His}_{6}$ residues was constructed on a pET28a vector. LipT expression in $E$. coli BL21 (DE3) increased in a time-dependent manner (Fig. 4A), mainly resulting in inclusion body formation. Purification of LipT was carried out with $8 \mathrm{M}$ urea using a 1-ml HisTrap column. LipT was eluted at 70 $\mathrm{mM}$ imidazole, as shown in Fig. $4 \mathrm{~B}$, suggesting that it bound weakly to the nickel resin. LipT was refolded by reducing the urea concentrations, but only a small fraction of LipT was refolded such that it resulted in lipase activity. 


\begin{tabular}{|c|c|c|}
\hline LipT & MGLFDYKNADGKALYSDAIALTLYAYTPTGQPLPATAWAPIGAKQLGYQGKVGAQGTFYG & 60 \\
\hline $23 \mathrm{KCS} 9$ & 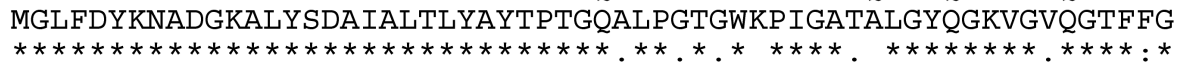 & 60 \\
\hline $\begin{array}{l}\text { LipT } \\
\text { Q3KCS9 }\end{array}$ & $\begin{array}{l}\text { EKDGFTSAEAEVLGKYDTAGKLIGIGIAFRGTGGLGYSDTFGDMKNNLLAAVGPVDYATN } \\
\text { EKDGFTSAEAEVLGKYDAAGKLIGIGVAFRGTGGLGYSDTFGDMKNNLLAAIGPSDYATQ } \\
* * * * * * * * * * * * * * * * * * * * * * *: * * * * * * * * * * * * * * * * * * * * * * * * * *\end{array}$ & $\begin{array}{l}120 \\
120\end{array}$ \\
\hline $\begin{array}{l}\text { LipT } \\
\text { Q3KCS9 }\end{array}$ & $\begin{array}{l}\text { YAKNAFDNLLKDVAAFS IAHGLSARDVMVSGHSLGGLGVNSLAELSGNNWGGFYKDANYI } \\
\text { YAKNAFDNLLKSVAAFAVAHGIAAKDVLVSGHSLGGLGVNSVAELSASNWGGFFKDANYI } \\
* * * * * * * * * * . * * *:: * * *::^{*}: * * * * * * * * * * * *: * * * \ldots * * * * * * * * * *\end{array}$ & $\begin{array}{l}180 \\
180\end{array}$ \\
\hline $\begin{array}{l}\text { LipT } \\
\text { 23KCS9 }\end{array}$ & $\begin{array}{l}\text { AFASPTQSATGNNVLNIGYENDPVFRVLDGTTFSSGSLGKHDGHQDSATNNIVNFNDQYA } \\
\text { SFASPTQSSTGTNVLNIGYENDPVFRVLDGTTFSTASMGKHDKPHDSTTDNIVNFNDNYA } \\
: * * * * * * * * * * * * * * * * * * * * * * * * * * * * *: * * * * * \quad: * *: * * * * * * * * * *\end{array}$ & $\begin{array}{l}240 \\
240\end{array}$ \\
\hline $\begin{array}{l}\text { LipT } \\
\text { 23KCS9 }\end{array}$ & $\begin{array}{l}\text { STAQNLVPFSILNPLNWSAHGSLGYADGLNRVIDSRFYDLTDKDSTLIVSNLAESSRGTT } \\
\text { STAQNLVPFSIANPLNWSAHSSLGYADGLNRVIASKFYGLTHKDSTIIVSNLEDASRGKT } \\
\star * * * * * * * * * * * * * * * * . * * * * * * * * * * * * * * * * * * *: * * * * *: * * * . *\end{array}$ & $\begin{array}{l}300 \\
300\end{array}$ \\
\hline $\begin{array}{l}\text { LipT } \\
\text { Q3KCS9 }\end{array}$ & $\begin{array}{l}\text { WVEDLGRSGEPHTGSTFI IGTDSDDLLKGGAGNDF IEGRDGNDRLRDDGGYNLLLGGKGS } \\
\text { WVEDLGRSGEPHTGSTFIIGTDSGDWLKGGAGNDFLEGLGGDDRFRDDGGFNILLGGQGH } \\
\star * * * * * * * * * * * * * * * * * * * * * * * * * * * * * * . *: * * * * * * * * * * * *: *\end{array}$ & $\begin{array}{l}360 \\
360\end{array}$ \\
\hline $\begin{array}{l}\text { LipT } \\
\text { Q3KCS9 }\end{array}$ & $\begin{array}{l}\text { NTFELQKPLQNFSFANDGDGTLYVRDAYGGISMTRDIGSLVSKESGSWWGSKEVTYSVTA } \\
\text { NTFELQKPLQNFSFANDGDGTLYVRDAYGGISMTRDIGALVSKESGSWWGSKEITWTVTA } \\
* * * * * * * * * * * * * * * * * * * * * * * * * * * * * * * * * * * * * * * * * * * * * * * *: *: * * *\end{array}$ & $\begin{array}{l}420 \\
420\end{array}$ \\
\hline $\begin{array}{l}\text { LipT } \\
\text { Q3KCS9 }\end{array}$ & $\begin{array}{l}\text { NGLLNGSELTHYNHSLNGDAYGNTLAASVDGDWLFGHAGDDLLRSDKSQVTFVGGAGNDL } \\
\text { KGLANGAELTQYNHSLSGGAMGDTLKATADGDWLFGLGGNDHLQSDKAHVTFVGGAGNDV } \\
: * * * *: * * *: * * * * . * * * * * * *: * * * * * * . * * * * * * *: * * * * * * * *\end{array}$ & $\begin{array}{l}480 \\
480\end{array}$ \\
\hline $\begin{array}{l}\text { LipT } \\
\text { Q3KCS9 }\end{array}$ & $\begin{array}{l}\text { MQASGGHNTFLFSGAFGFDAINGYQGNDKLVFLGVQGAGQGYDYKQHASQSGHDTVLKVG } \\
\text { MSAVGGNNTFLFSGAFGFDAINGYQGSDKLVFMGVEGAGQGYDYKQHASQSGSDTVLKIG } \\
* \text { * ** }: * * * * * * * * * * * * * * * * * . * * * * * * *: * * * * * * * * * * * * * * * * * * *\end{array}$ & $\begin{array}{l}540 \\
540\end{array}$ \\
\hline CS 9 & $\begin{array}{l}\text { DFAVTLVGVGLDSLSASGITFA } 562 \\
\text { DFAVTLIGVGVANLSDSSFVFA } 562 \\
* * * * * * * *: . * * * . . * * *\end{array}$ & \\
\hline
\end{tabular}

Fig. 3. Multiple amino acid sequence alignment. The amino acid sequence of LipT was compared with the $P$. fluorescens Pf0-1 lipase (Q3KCS9). The GXSXG motif (purple) of serine enzymes and the GGXGXD and GXXGXD motifs (cyan) for ABC transporters are denoted, respectively.
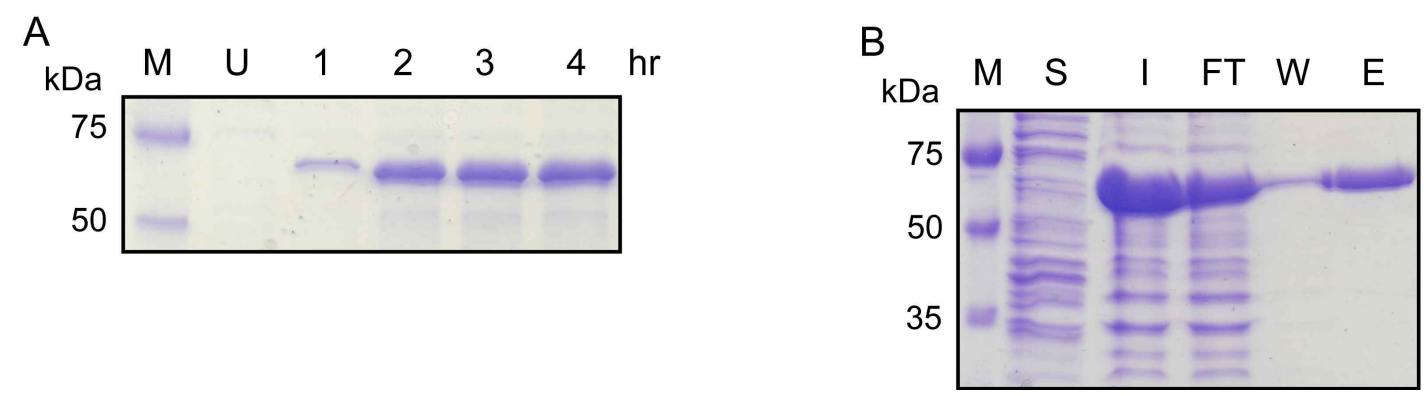

Fig. 4. Expression and purification of LipT. (A) LipT was expressed in E. coli BL21 (DE3) upon 1 mM IPTG induction. U, uninduced. (B) Purification of LipT using nickel-chelate affinity chromatography. M, molecular weight marker; Lane S, soluble fraction after sonication; Lane I, Input from inclusion bodies; Lane FT, Flow-through; Lane W, Wash buffer (5 mM imidazole); Lane E, Elution buffer (70 mM imidazole). The calculated molecular weight of LipT was 59,055 Da and it migrated on a SDS gel as a $64 \mathrm{kDa}$ protein.

\section{Substrate specificity of LipT}

Of all the p-nitrophenyl esters (C2 to C16) tested, LipT exhibited maximal hydrolysis with PNPB (C4) (Fig. 5). The hydrolysis of PNPO (C8) was approximately $71 \%$ of that observed for PNPB. LipT showed no enzymatic activity for other p-nitrophenyl esters (C2 and C12-16). 


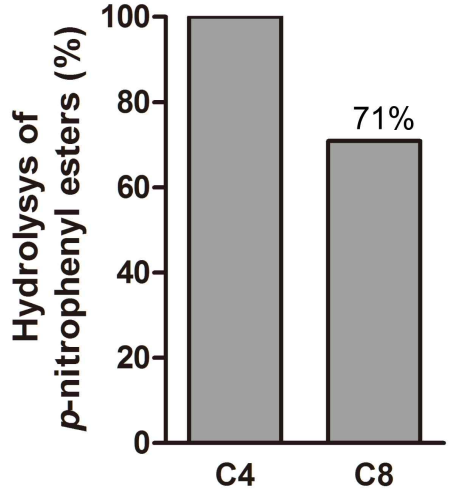

Fig. 5. Hydrolysis of pnitrophenyl esters by LipT. The hydrolysis of the p-nitrophenyl esters (C2 to $\mathrm{C} 16$ ) was expressed as a percentage comparison to PNPB. There was no activity observed with $\mathrm{C} 2$ and $\mathrm{C} 12$ to $\mathrm{C} 16$ substrates. $100 \%=1.4 \mu \mathrm{M} / \mathrm{min}$.

A few other lipases demonstrated substrate preferences for medium-chain fatty acids which were similar to that of LipT. A lipase from a cold-adapted Psychrobacter sp. exhibited the highest hydrolytic activity with p-nitrophenyl caproate (C6), followed by PNPB [14]. Medium-chain acyl group pnitrophenyl esters were also good substrates for psychrotrophic Pseudomonas sp. KB700A lipase (C10>C6>C4) [15]. A lipase from psychrotrophic Aeromonas sp. LPB4 favored substrates containing medium chain acyl groups (C3 to $\mathrm{C} 10)$ [11].

In conclusion, lipT, a gene coding for a lipase, was cloned from the psychrotrophic bacterium $P$. mandelii JR-1 and sequenced. The recombinant LipT protein was expressed in E. coli BL21 (DE3), mainly as inclusion bodies. LipT demonstrated substrate preferences for esters of medium-chain fatty acids (C4 and C8).

\section{Acknowledgement}

This work was supported by the Daegu University Research Grant, 2008 (to C. L.).

\section{References}

1. Ahn, J. H., Pan, J. G. and Rhee, J. S. 1999. Identification of the tliDEF ABC transporter specific for lipase in Pseudomonas fluorescens SIK W1. J. Bacteriol. 181, 1847-1852.

2. Bell, P. J., Sunna, A., Gibbs, M. D., Curach, N. C., Nevalainen, H. and Bergquist, P.L. 2002. Prospecting for novel lipase genes using PCR. Microbiology 148, 2283-2291.

3. Chahinian, H. and Sarda, L. 2009. Distinction between esterases and lipases: comparative biochemical properties of se- quence-related carboxylesterases. Protein Pept. Lett. 16, 1149-1161.

4. Chun, J., Lee, J. H., Jung, Y., Kim, M., Kim, S., Kim, B. K. and Lim, Y. W. 2007. EzTaxon: a web-based tool for the identification of prokaryotes based on 16S ribosomal RNA gene sequences. Int. J. Syst. Evol. Microbiol. 57, 2259-2261.

5. Chung, C. W., You, J., Kim, K., Moon, Y., Kim, H. and Ahn, J. H. 2009. Export of recombinant proteins in Escherichia coli using $\mathrm{ABC}$ transporter with an attached lipase $\mathrm{ABC}$ transporter recognition domain (LARD). Microb. Cell Fact. 8, 11.

6. Cygler, M., Schrag, J. D., Sussman, J. L., Harel, M., Silman, I., Gentry, M. K. and Doctor, B. P. 1993. Relationship between sequence conservation and three-dimensional structure in a large family of esterases, lipases, and related proteins. Protein Sci. 2, 366-382.

7. Gratia, E., Weekers, F., Margesin, R., D'Amico, S., Thonart, P. and Feller, G. 2009. Selection of a cold-adapted bacterium for bioremediation of wastewater at low temperatures. Extremophiles 13, 763-768.

8. Jaeger, K. E., Dijkstra, B. W. and Reetz, M. T. 1999. Bacterial biocatalysts: molecular biology, three-dimensional structures, and biotechnological applications of lipases. Annu Rev. Microbiol. 53, 315-351.

9. Joseph, B., Ramteke, P. W. and Thomas, G. 2008. Cold active microbial lipases: some hot issues and recent developments. Biotechnol. Adv. 26, 457-470.

10. Kouker, G. and Jaeger, K. E. 1987. Specific and sensitive plate assay for bacterial lipases. Appl. Environ. Microbiol. 53, 211-213.

11. Lee, H. K., Ahn, M. J., Kwak, S. H., Song, W. H. and Jeong, B. C. 2003. Purification and characterization of cold active lipase from psychrotrophic Aeromonas sp. LPB 4. J. Microbid. 44, 22-27.

12. Moyes, R. B., Reynolds, J. and Breakwell, D. P. 2009. Differential staining of bacteria: gram stain. Curr. Protoc. Microbiol. Appendix 3, Appendix 3C.

13. Mulet, M., Lalucat, J. and Garcia-Valdes, E. 2010. DNA sequence-based analysis of the Pseudomonas species. Environ Microbiol. 12, 1513-1530.

14. Parra, L. P., Reyes, F., Acevedo, J. P., Salazar, O., Andrews, B. A. and Asenjo, J. A. 2008. Cloning and fusion expression of a cold-active lipase from marine Antarctic origin. Enzyme Microb. Technol. 42, 371-377.

15. Rashid, N., Shimada, Y., Ezaki, S., Atomi, H. and Imanaka, T. 2001. Low-temperature lipase from psychrotrophic Pseudomonas sp. strain KB700A. Appl. Environ. Microbiol. 67, 4064-4069.

16. Rosenau, F. and Jaeger, K. 2000. Bacterial lipases from Pseudomonas. regulation of gene expression and mechanisms of secretion. Biochimie 82, 1023-1032.

17. Silby, M. W. et al. 2009. Genomic and genetic analyses of diversity and plant interactions of Pseudomonas fluorescens. Genome Biol. 10, R51.

18. Tutino, M. L., di Prisco, G., Marino, G. and de Pascale, D. 2009. Cold-adapted esterases and lipases: from fundamentals to application. Protein Pept. Lett. 16, 1172-1180. 
초록 : Pseudomonas mandelii의 lipase 유전자 클로닝, 발현 및 정제

김준성 $\cdot$ 이창우*

(대구대학교 의생명과학과)

내냉성 세균인 Pseudomonas mandelii로부터 lipase 유전자(lipT)를 클로닝하고 염기서열을 분석하였다. 열린해독틀 (open reading frame)은 1,686 bp로 구성되어 있고, 562개의 아미노산을 코딩한다. 서열분석 결과 많은 세린 효소에 서 발견되는 Gly-X-Ser-X-Gly 모티프가 존재한다(Gly-His-Ser-Leu-Gly). 재조합 LipT 단백질은 대장균에서 주로 inclusion body 형태로 발현되었다. 니켈 친화성 크로마토그라피 방법으로 LipT 단백질을 분리하였으며 소량의 LipT 단백질이 refold 되었다. 이 효소는 pnitrophenyl butyrate (C4)과 pnitrophenyl octanoate (C8)에 대해 기질 특이성 을 나타내었다. 